University of Nebraska - Lincoln

DigitalCommons@University of Nebraska - Lincoln

Faculty Publications: Department of Entomology

Entomology, Department of

June 1998

Uptake and Bioconcentration of Atrazine by Selected Freshwater Algae

Jixin Tang

University of Nebraska-Lincoln

Kyle D. Hoagland

University of Nebraska-Lincoln, khoagland1@unl.edu

Blair Siegfried

University of Nebraska-Lincoln, bsiegfried1@ufl.edu

Follow this and additional works at: https://digitalcommons.unl.edu/entomologyfacpub

Part of the Entomology Commons

Tang, Jixin; Hoagland, Kyle D.; and Siegfried, Blair, "Uptake and Bioconcentration of Atrazine by Selected Freshwater Algae" (1998). Faculty Publications: Department of Entomology. 134.

https://digitalcommons.unl.edu/entomologyfacpub/134

This Article is brought to you for free and open access by the Entomology, Department of at DigitalCommons@University of Nebraska - Lincoln. It has been accepted for inclusion in Faculty Publications: Department of Entomology by an authorized administrator of DigitalCommons@University of Nebraska - Lincoln. 
Published in Environmental Toxicology and Chemistry 17:6 (June 1998), pp. 1085-1090.

Copyright (C) 1998 SETAC Press; published by Elsevier, Inc. Used by permission. doi 10.1897/1551-5028(1998)017<1085:UABOAB>2.3.CO;2

Submitted January 17, 1997; accepted September 19, 1997.

\title{
Uptake and Bioconcentration of Atrazine by Selected Freshwater Algae
}

\author{
Jixin Tang ${ }^{1}$, Kyle D. Hoagland ${ }^{2}$, and Blair D. Siegfried ${ }^{1, *}$ \\ 1. Department of Entomology, 202 Plant Industry Building, University of Nebraska, Lincoln, Nebraska 68583, USA \\ 2. Department of Forestry, Fisheries and Wildlife, 101 Plant Industry Building, University of Nebraska, Lincoln, Nebraska 68583, USA

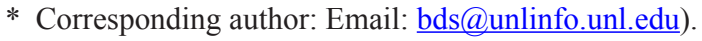

\begin{abstract}
Atrazine bioconcentration and uptake were determined for eight freshwater green algae and diatoms. Atrazine uptake was extremely rapid in all species examined, with nearly $90 \%$ of total uptake occurring within the first hour of exposure. Within each division, different species had different bioconcentration capacities, although the accumulation of atrazine was consistently higher in green algae $(5.43-12.73 \mathrm{ng} / \mathrm{mg})$ than in diatoms $(0.33-1.69 \mathrm{ng} / \mathrm{mg})$. Atrazine concentrations in the algal cells were much higher than in the medium, although the total amount of atrazine taken up by algae was small relative to the total atrazine in solution (1-3\%). The ability of algal cells to accumulate atrazine was highly correlated with algal cell biovolume and surface area, and a strong relationship was observed between sensitivity to atrazine and bioconcentration, cell biovolume, and surface area. In general, higher bioconcentration factors were associated with increased atrazine sensitivity.
\end{abstract}

Keywords: Atrazine, Bioconcentration, Freshwater algae, Cell size

\section{INTRODUCTION}

Atrazine (2-chloro-4-ethylamino-6-isopropylamino-s-triazine) is one of the most widely used pesticides for controlling certain annual broadleaf weeds and grasses in North America. As a result of its widespread use and relatively high water solubility and persistence, it has been identified as a principal contaminant of surface waters [1]. The documented presence of atrazine in surface waters has prompted a large number of studies on its potential adverse effects on aquatic organisms. A comprehensive database of ecological effects of atrazine, including toxicity testing with 47 saltwater species and 85 freshwater organisms, was recently compiled, indicating that freshwater algae are among the most susceptible of all aquatic species [1].

Recent studies have indicated that different algal divisions and species apparently have different sensitivity to atrazine [13] and that algal responses to atrazine vary widely depending upon concentrations used, duration of exposure, and algal species tested. Recently, we compared atrazine susceptibility of four diatoms and four green algae over 7- to 28-d exposures [4]. Generally, there was a broad range of sensitivity among species and between divisions of algae tested, with green algae being 4 to 10 times more sensitive to atrazine than diatoms.

Herbicides recommended for the selective control of unwanted weeds have been developed to exploit differences in phytotoxicity between species and are effective at killing competing weeds without significantly reducing crop yields [5]. The selective properties of herbicides often result from a complex interaction of a number of factors including (1) differential uptake of herbicides, (2) differential metabolism of herbicides to nontoxic end products, and (3) differential sensitivity of the target sites. However, there are many examples where one dominant factor has been implicated. This is certainly true in the case of herbi- cide uptake and movement in vascular plants [6]. Significant differences in uptake of three herbicides among three divisions of freshwater algae (green algae, blue-green algae, and diatoms) have been reported [7]. Such differences could also contribute to differences in herbicide toxicity among freshwater algae.

Atrazine inhibits photosynthesis of most plants, including freshwater algae, and its mode of action involves competition for binding to the $\mathrm{Q}_{\mathrm{B}}$ protein (32-kDa protein) with plastoquinone in photosystem II $[8,9]$. To inhibit the photosynthetic process of freshwater algae, atrazine must be absorbed intracellularly. The sorption of the herbicide to algal cells is a prerequisite for its action at the chloroplast membrane. The objectives of the present study were to examine whether bioconcentration capacities of freshwater algae are related to differential sensitivity to atrazine and to examine the biophysical properties (volume and surface area) of the algal cell that may affect atrazine bioconcentration.

\section{MATERIALS AND METHODS}

\section{Algal species and culture conditions}

Four species of green algae and four species of diatoms were used in all experiments. Test species were selected based on their availability in culture collections and their ability to grow under similar conditions (temperature, lighting, and nutrition). Green algae (Chlamydomonas sp., Chlorella sp., Pediastrum sp., and Scenedesmus quadricauda) were obtained from Carolina Biological Supply (Burlington, NC, USA). Diatoms (Cyclotella gamma, C. meneghiniana, Synedra acus, and S. radians) were obtained from the Loras College culture collection (Dubuque, IA, USA). All algae were grown under axenic conditions. Green algae were grown in WC freshwater medium [10], 
and diatoms were grown in modified Chu\#10 medium [11]. Cultures were incubated at $20^{\circ} \mathrm{C}$ with alternate $14 / 10$ light/dark cycle using cool white fluorescent light. Cultures were shaken at $110 \mathrm{rpm}$ for 7 to $10 \mathrm{~d}$ to obtain algal cultures in exponential growth phase.

\section{Chemicals}

${ }^{14} \mathrm{C}$-atrazine (ring-UL, specific activity $26 \mu \mathrm{Ci} / \mu \mathrm{mol}$ ) was purchased from Sigma Chemical (St. Louis, MO, USA) and purified by thin-layer chromatography in ethyl acetate:hexane (45:55 v/v) before initiating experiments. Tissue and gel solubilizer (SOLVABLETM) was obtained from NEN Research Products (Boston, MA, USA). Scintillation cocktail (Ecolite ${ }^{\mathrm{TM}}$ ) was obtained from ICN Biochemicals (Irvine, CA, USA).

\section{Dry mass measurement}

A method modified from Tan et al. [12] was used to determine the relationship between dry mass and optical density of the freshwater algae. A stock algal cell suspension (14-15 d old) was diluted with growth medium into a dilution series with varying optical densities. After measurement of optical densities at 680 $\mathrm{nm}$, dilutions of the cell suspensions were filtered through a preweighed Whatman GF/A filter, which was then dried at $105^{\circ} \mathrm{C}$ for $2 \mathrm{~h}$ and weighed again. Three replicate samples were measured for each dilution. The relationships between dry mass (milligrams per milliliter) and optical density $\left(\mathrm{OD}_{680}\right)$ were determined by regression analysis for each species. A strong correlation between optical densities and dry mass of the algae tested was obtained with $r^{2}$ values $>0.978$ for all species tested, indicating that optical density of algal cell suspensions could be used to estimate dry mass for each species.

\section{Uptake and bioconcentration of atrazine by freshwater algae}

Prior to initiating uptake experiments, $\mathrm{OD}_{680}$ was measured for each species, and the concentrations were adjusted with sterilized medium to $0.1 \mathrm{mg}$ dry mass per milliliter of suspension based on previously determined calibration curves of $\mathrm{OD}_{680}$ versus dry mass. Algal suspensions ( $15 \mathrm{ml})$ were distributed into autoclaved test tubes, and ${ }^{14} \mathrm{C}$-atrazine diluted in ethanol was added to each tube to achieve a final atrazine concentration of $40 \mu \mathrm{g} / \mathrm{L}$, which was sublethal to all species tested [4].

The test tubes were incubated under the same conditions as stock cultures, and, at various time intervals $(5,30$, and $60 \mathrm{~min}$ and 3, 6, and $24 \mathrm{~h}$ ) after addition of ${ }^{14} \mathrm{C}$-atrazine, four test tubes were randomly withdrawn and their $\mathrm{OD}_{680}$ was measured. The entire sample was then filtered through a Whatman GF/C glass fiber filter to collect algal cells. The filters were washed with $3 \times 5$ $\mathrm{ml}$ of cold atrazine solution $(0.5 \mathrm{ppm})$ to displace labeled atrazine that was loosely absorbed to the cell surface. Filters were then placed in scintillation vials containing two drops of bleach to decolorize the sample and $0.5 \mathrm{ml}$ of tissue solubilizer to release internalized radioactivity. The filters were then incubated for $3 \mathrm{~h}$ at $45^{\circ} \mathrm{C}$. Radioactivity present in both the filtered cells and in 1-ml aliquots of the growth medium was determined by liquid scintillation counting. Sample counts were corrected for quenching. Counting efficiency was automatically determined with a ${ }^{14} \mathrm{C}$ internal standard program. Uptake was measured from four different suspensions for each species.
Measurement of cell volume and surface area of the freshwater algae

A minimum of 25 cells from late-exponential or stationary phase (9- to 10-d-old) cultures (in absence of atrazine) were randomly selected using a hemocytometer grid to determine mean cell volume and surface area for each species [2]. Appropriate geometric shapes (i.e., Chlamydomonas, sphere; Chlorella, sphere; $P e-$ diastrum, each cell in colony is a flat cylinder; Scenedesmus quadricauda, cylinder; Cyclotella, cylinder; and Synedra, rectangular box) were chosen for each test species, and cell biovolume and surface area were calculated using the BIOVOL program [13]. Cellular dimensions (e.g., length, width, and depth) were measured according to the designated geometric form using an ocular micrometer-equipped Nikon compound microscope.

\section{Data analysis}

The methods used to quantify atrazine uptake do not distinguish between absorption (internalization) and adsorption to the cell surface $[14,15]$. Therefore, the term uptake was used to designate the combination of these two processes. To compensate for radioactivity bound to filters in the absence of algae, all sample counts were compared to controls containing only medium and ${ }^{14} \mathrm{C}$-atrazine. The radioactivity present in blanks was subtracted from the counts present in the cells. Atrazine uptake was expressed as nanograms of atrazine per milligram of dry mass and nanograms of atrazine per cubic millimeter of algal biovolume. Uptake percentage of the amount of atrazine initially available in solution was also calculated.

Bioconcentration of chemicals by aquatic organisms is generally expressed as the bioconcentration factor (BCF), which is the ratio of the substance's concentration sorbed to the organism to that dissolved in the surrounding medium [15-17]. Atrazine BCFs were calculated for each species by dividing the adsorption density of atrazine taken up by algae (expressed both in biovolume and dry mass) by the concentration of atrazine remaining in the growth medium. Significant differences among the BCFs were determined by analysis of variance, and differences among treatment means were determined by Duncan's multiple range test [18].

The relationship among atrazine toxicity, BCF, and cell size (volume and surface area) and the relationship among total atrazine uptake, total cell volume, and total cell surface area were analyzed by linear regression analysis. The analysis of variance for each regression was used to estimate significant relationships.

\section{Cell size}

\section{RESULTS}

Individual cell biovolume and surface area varied widely among the algal species tested (Table 1), although, in general, the diatoms selected were larger than green algae. The total standing crop biovolume (cubic millimeters) and surface area (square millimeters) at $24 \mathrm{~h}$ of the algal species tested were also calculated based on individual cell biovolume, surface area, and cell density in the medium (Table 1). It is apparent that green algae had greater total biovolume and surface area than diatoms at the same dry mass concentration $(0.1 \mathrm{mg} / \mathrm{ml})$, indicating that diatoms were more dense than green algae. Therefore, both dry mass and biovolume were used in calculating atrazine uptake and bioconcentration for each species. 
Table 1. Cell size and standing crop of the freshwater algae tested ${ }^{\mathrm{a}}$

\begin{tabular}{|c|c|c|c|c|}
\hline \multirow[b]{2}{*}{ Division/species } & \multicolumn{2}{|c|}{ Individual cell } & \multicolumn{2}{|c|}{ Total standing crop at $24 \mathrm{~h}^{\mathrm{a}}$} \\
\hline & Biovolume $\left(\mu \mathrm{m}^{3}\right)^{\mathrm{b}}$ & Surface area $\left(\mu m^{2}\right)^{b}$ & Biovolume $\left(\mathrm{mm}^{3}\right)^{\mathrm{b}}$ & Surface area $\left(\mathrm{mm}^{2}\right)^{b}$ \\
\hline \multicolumn{5}{|l|}{ Chlorophyta } \\
\hline Chlamydomonas sp. & $927.63 \pm 16.42$ & $460.09 \pm 8.24$ & $1.85 \pm 0.08$ & $916.30 \pm 16.38$ \\
\hline Chlorella sp. & $118.85 \pm 6.53$ & $116.93 \pm 5.68$ & $2.22 \pm 0.16$ & $2,181.14 \pm 24.43$ \\
\hline Pediastrum sp. & $1,157.50 \pm 25.24$ & $752.68 \pm 12.35$ & $3.87 \pm 0.11$ & $2,516.02 \pm 45.23$ \\
\hline $\begin{array}{l}\text { Scenedesmus } \\
\text { quadricauda }\end{array}$ & $174177+2682$ & $80995+1586$ & $233+009$ & $108406+1868$ \\
\hline \multicolumn{5}{|l|}{ Bacillariophyta } \\
\hline Cyclotella gamma & $10,052.31 \pm 86.64$ & $2,626.87 \pm 35.58$ & $1.08 \pm 0.01$ & $282.15 \pm 5.63$ \\
\hline C. meneghiniana & $6,128.88 \pm 58.64$ & $1,857.02 \pm 24.38$ & $1.46 \pm 0.02$ & $443.23 \pm 13.65$ \\
\hline Synedra acus & $5,051.50 \pm 55.64$ & $2,648.55 \pm 23.46$ & $1.07 \pm 0.01$ & $562.11 \pm 14.68$ \\
\hline S. radians & $1,017.50 \pm 32.21$ & $803.94 \pm 22.14$ & $1.31 \pm 0.01$ & $1,033.51 \pm 21.45$ \\
\hline
\end{tabular}

a Total standing crop was obtained from calibration curves of $\mathrm{OD}_{680}$ versus cell density using $\mathrm{OD}_{680}$ at $24 \mathrm{~h}$ in the uptake experiment in $15 \mathrm{ml}$ of medium. Total volume or surface area $=$ biovolume or surface area/cell* total cells in $15 \mathrm{ml}$ medium.

${ }^{\mathrm{b}}$ Mean $\pm \operatorname{SE}(n=25)$.

\section{Bioconcentration of atrazine}

The kinetics of atrazine uptake in each algal species based on dry mass, biovolume, and percent of total are shown in Figure 1. Atrazine, which is a moderately lipophilic compound with a log $K_{\text {ow }}$ of 2.56 at $25^{\circ} \mathrm{C}$ [19], was rapidly taken up from the medium by all the algal species tested. Nearly $90 \%$ of maximum atrazine uptake by a given species occurred within the first hour of exposure.



Figure 1. Uptake of atrazine by freshwater algae based on algal dry mass (A), cell biovolume (B), and percentage of total atrazine available in solution (C). Diatoms: Cyclotella gamma - -; C. meneghiniana $\longrightarrow$ - Synedra acus $-\longrightarrow$ - S. radians $\longrightarrow-$ . Chlorophyta: Chlamydomonas sp. $\cdots \cdot \square \cdot \cdots \cdots$; Chlorella sp. $\cdots \cdots \diamond \cdots \cdots$; Pediastrum sp. $\cdots \cdot \cdots \cdot \cdots \cdot$; Scenedesmus quadricauda $\cdots \cdot \triangle \cdots \cdots$.
However, the green algae tested continued to exhibit a slight increase in atrazine concentration up to $6 \mathrm{~h}$ but did not change significantly between 6 and $24 \mathrm{~h}$. In contrast, the diatoms exhibited little change or even a slight decrease in atrazine concentration beyond 3 h. Although atrazine concentrations within algal cells reached their maximum very quickly, the total amount of atrazine taken up was very small. For green algae, the percentage of atrazine taken up did not exceed $3 \%$ of the available atrazine in solution, and, for diatoms, the percentage taken up did not exceed 1\% (Figure 1C). Recovery of ${ }^{14} \mathrm{C}$-atrazine was $\geq 90 \%$ for all species tested.

The 24-h exposure data were used to calculate bioconcentration capacities among algal species (Table 2), based on both dry mass and biovolume. There were large differences in uptake abilities among species and between the two divisions of freshwater algae tested. Results indicated that the uptake of atrazine by green algae was significantly greater than that of diatoms after 24 h. The BCFs of green algae were significantly $(p<0.05)$ greater than those of diatoms in all instances. At $24 \mathrm{~h}$, the BCFs of green algae ranged from 130.5 to 324.1 based on dry mass and 94.4 to 200.9 based on cell biovolume, whereas the BCFs for diatoms ranged from 8.0 to 45.5 and 11.7 to 69.4 for dry mass and biovolume, respectively.

Table 2. Atrazine bioconcentration factors in freshwater algae

\begin{tabular}{lcc}
\hline & \multicolumn{2}{c}{ Bioconcentration factors $^{2}$} \\
\cline { 2 - 3 } Division/species & Dry mass ${ }^{\mathrm{a}}$ & Biovolume $^{\mathrm{a}}$ \\
\hline Chlorophyta & & \\
$\quad$ Chlamydomonas sp. & $175.4 \pm 7.4 \mathrm{~b}$ & $167.4 \pm 7.3 \mathrm{~b}$ \\
$\quad$ Chlorella sp. & $172.7 \pm 11.7 \mathrm{~b}$ & $200.9 \pm 13.3 \mathrm{a}$ \\
Pediastrum sp. & $324.1 \pm 15.7 \mathrm{a}$ & $121.3 \pm 13.4 \mathrm{c}$ \\
Scenedesmus & & \\
$\quad$ quadricauda & $130.5 \pm 8.2 \mathrm{c}$ & $94.4 \pm 2.7 \mathrm{~d}$ \\
Bacillariophyta & $40.9 \pm 2.2 \mathrm{~d}$ & $69.4 \pm 3.4 \mathrm{e}$ \\
Cyclotella gamma & $8.0 \pm 0.9 \mathrm{e}$ & $11.7 \pm 2.9 \mathrm{~g}$ \\
C. meneghiniana & $42.2 \pm 1.9 \mathrm{~d}$ & $63.4 \pm 2.9 \mathrm{ef}$ \\
$\quad$ Synedra acus & $45.5 \pm 2.7 \mathrm{~d}$ & $47.2 \pm 3.0 \mathrm{f}$ \\
S. radians & & \\
\hline
\end{tabular}

a Bioconcentration factors (mean $\pm \mathrm{SE}$ ) within columns followed by a common letter are not significantly different $(p<0.05$; Duncan's multiple range test). Each value derived from three samples with three measurements per sample. 


\section{Toxicity correlation}

The quantitative correlation between atrazine toxicity and algal cell size was determined by regression analysis. Toxicity measurements were derived previously from estimates of values of concentration with 50\% effectiveness (EC50) based on reduction in chlorophyll $a$ content after $14 \mathrm{~d}$ of exposure for the same algal species used in uptake and bioconcentration experiments [4]. The relationship among algal cell biovolume, surface area, surface to volume ratio, and BCF (based on both dry mass and biovolume) with EC50 values were examined (Figure 2). Both cell volume and surface area were significantly correlated with toxicity, although the surface to volume ratio was only significant at $p$ $<0.1$. There was no significant correlation with BCF when estimated based on dry mass or biovolume. Cell biovolume provided the strongest predictor of algal sensitivity to atrazine exposure.

\section{DISCUSSION}

The results of this study indicate that the various freshwater algal species differ significantly in their capacity to accumulate atrazine from solution and that the examined green algae accumulate higher concentrations of atrazine than diatoms. Within each algal division studied, different species also displayed different bioconcentration capacities. These differences could be due to specific morphological and physiological characteristics of the cells, such as lipid content, and the structure and composition of cell walls. Additionally, differences in cell size and density appear to contribute to differences in atrazine bioconcentration. The characteristic high surface area to biovolume ratio of freshwater algae suggests a high potential for sorption and subsequent interaction with pesticides. In general, results of this investigation indicate that species having a smaller cell size accumulated higher amounts of atrazine relative to larger species. These results are consistent with those of Rice and Sikka [20], who reported similar results for dichlorodiphenyltrichloroethane accumulation.

A significant correlation was observed between cell size and toxicity to the freshwater algae studied. This correlation suggests that different degrees of atrazine accumulation might contribute to differences in the toxicity of atrazine and that bioconcentration might be a prerequisite for toxicity. A similar correlation between bioconcentration and toxicity has been observed in other algal species [2,13]. Algal cell size and morphology has been shown to play an important role in nutrient uptake, photosynthesis, respiration, and regulation of waste products [2]. It is likely that the admission of toxicants and the subsequent response may also be a function of cell size. Similar correlations have been associated with pollution tolerance in zooplankton [21] and in phytoplankton where toxic response has been correlated with cell size [22,23]. Kent and Currie [2] observed that the ratio of the square root of surface area to the cubic root of volume was a good predictor of algal sensitivity to the insecticide fenitrothion. In contrast to their results, the strongest predictor of algal sensitivity in our study was cell biovolume. Generally, green algae were smaller in

Figure 2 Correlation between atrazine toxicity (see text for detail) and cell size as measured by cell biovolume (A), surface area (B), the surface to volume ratio $(\mathbf{C})$, and BCFs based on both dry mass (D) and biovolume (E) for selected freshwater algal species. Diatoms represented by open circles and green algae by closed circles.
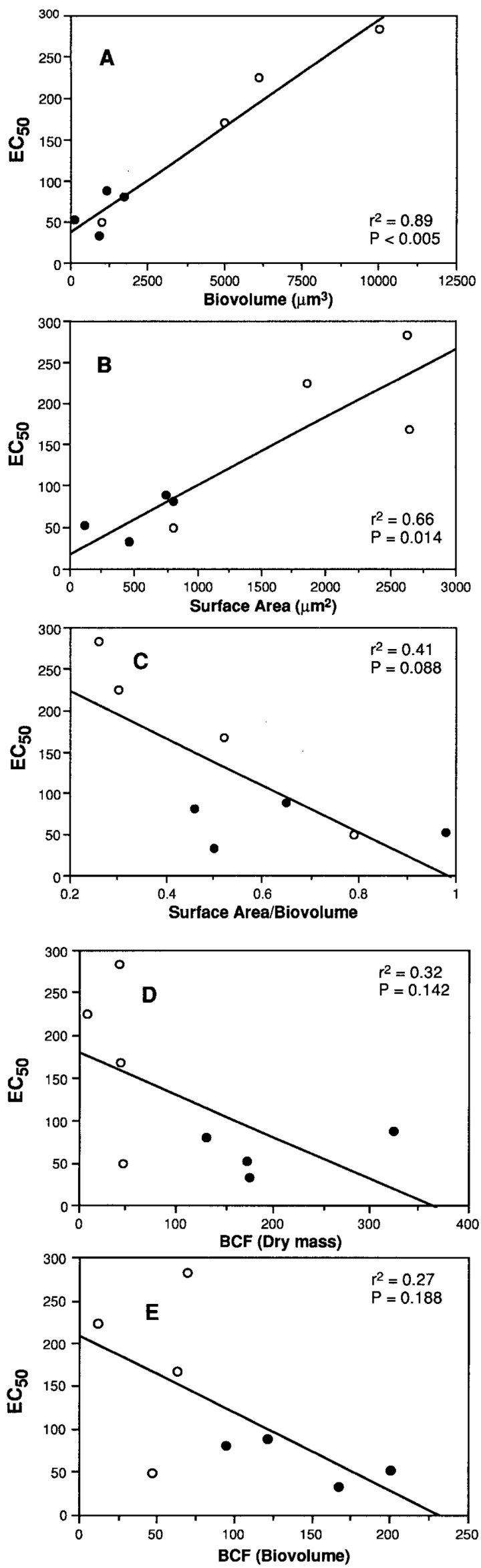
both biovolume and surface area than diatoms, and, the smaller the biovolume, the lesser the internal atrazine levels required to evoke inhibition. It should be noted that for at least one of the diatom species ( $S$. radians) tested, a smaller size was correlated with a higher sensitivity to atrazine despite a relatively low BCF. These results suggest that cell size influences bioconcentration of atrazine, and different degrees of bioconcentration, in turn, may affect atrazine toxicity. However, it should be noted that factors other than cell size, such as lipid content and cell structure, may influence bioconcentration of toxicants and subsequent toxicity.

The present results allow some insight into the mechanisms of the herbicide uptake in algal cells. Sorption of organic compounds by microorganisms is mainly a passive process that is driven by chemical partitioning into the hydrophobic biomass [24]. The time necessary to reach equilibrium for sorption appears to be very short and has been reported to vary from a few minutes to a few hours for other algal species [25-27]. It is well known that lipid-soluble substances easily pass into cells through the cell wall [28]. The uptake of atrazine by the algae examined was extremely rapid. During the first 1 to $3 \mathrm{~h}$ of exposure, all algal species reached 80 to $90 \%$ of their maximum uptake levels, which apparently represented an equilibrium concentration as the levels of atrazine uptake did not change significantly for up to 24 h. The uptake of atrazine by freshwater algae might be considered to consist of an initial rapid phase (a few minutes) due to the affinity of the atrazine molecule to the algal cell surface, which is independent of environmental conditions, followed by a slower uptake process, which may be due to membrane transport of atrazine into the algal cells. The transport of atrazine through the cell membrane into algal cells may be influenced by many factors, such as the structure and composition of the cell membranes and specific binding to photosystem II components of the chloroplast.

In summary, atrazine uptake by the freshwater algae tested was extremely rapid and reached a maximum level 3 to $6 \mathrm{~h}$ after initial exposure. The uptake appears to consist of two phases: an initial rapid phase due to the affinity of the atrazine molecule to the algal cell surface and a subsequent slower internalization, which may be due to membrane transport of atrazine into the algal cell. The accumulation of atrazine was consistently higher in green algae relative to diatoms, and, within each division, different species had different bioconcentration capacities. These differences are apparently correlated with differences in cell size among the two divisions. There was a strong relationship between algal sensitivity and cell size. The ability to bioconcentrate atrazine was highly correlated with cell volume and surface area in the tested algal species.

Bioconcentration and toxicity of pesticides, determined by the use of selected organisms from different trophic levels and taxonomic groups, are important criteria for ecological hazard assessment for aquatic environments [14]. Given the importance of freshwater algae as primary producers, an understanding of the mechanisms of atrazine-selective toxicity may allow assessment of community-level effects. Results from this investigation indicate that atrazine sensitivity among freshwater algae is related to bioconcentration capacity, and different levels of bioaccumulation seem to be at least partially attributable to different cell size (cell biovolume and surface area). The relationship among algal cell size, atrazine bioconcentration, and toxicity supports the idea that bioconcentration is a prerequisite for herbicide toxicity in al- gae and suggests that algal cell size may serve as an indicator of sensitivity. Although other factors may also play a role in algal sensitivity to atrazine, an integrated consideration of cell size, bioconcentration, and toxicity appears to be important to assessing atrazine effects on freshwater algae.

\section{Acknowledgments}

The authors thank Kenneth Pruess and Susan Jensen for their critical review of an earlier draft of this manuscript. This work was partially supported by the University of Nebraska Water Center and through a grant from the USGS Section 104 Program.

Journal Series paper 11725, Nebraska Agricultural Research Division, Lincoln, Nebraska, and contribution 938, Department of Entomology, University of Nebraska-Lincoln, Lincoln, Nebraska.

\section{REFERENCES}

1. Solomon KR. et al. 1996. Ecological risk assessment of atrazine in North America surface waters. Environ Toxicol Chem. 15:31-76.

2. Kent RA, and Currie D. 1995. Predicting algal sensitivity to a pesticide stress. Environ Toxicol Chem. 14:983-991.

3. Blanck H, Wallin G, and Wanberg S. 1984. Species-dependent variation in algal sensitivity to chemical compounds. Ecotoxicol Environ Saf. 8:339-351.

4. Tang J. 1996. Mechanisms of atrazine selective toxicity in freshwater algae. $\mathrm{PhD}$ thesis. University of Nebraska, Lincoln, NE, USA.

5. Hathway DE. 1989. Molecular Mechanisms of Herbicide Selectivity. Oxford Scientific, NY, USA.

6. Hess FD. 1985. Herbicide absorption and translocation and their relationship to plant tolerances and susceptibility. In Dude SO, ed, Weed Physiology, Vol 2-Herbicide Physiology. CRC, Boca Raton, FL, USA.

7. O'Kelly JD, and Deanson TR. 1976. Degradation of pesticides by algae. EPA 600/3-76-002. Final Report. U.S. Environmental Protection Agency, Athens, GA.

8. Velthuys BR. 1981. Electron dependent competition between plastoquinone and inhibitors for binding to photosystem II. FEBS Lett. 126:277-282.

9. Fuerst EP, and Norman MA. 1991. Interactions of herbicides with photosynthetic electron transport. Weed Sci. 39:458-464.

10. Guillard RRL. 1975. Culture of phytoplankton for feeding marine invertebrates. In Smith WL, Chanley MH, eds, Culture of Marine Invertebrate Animals. Plenum, New York, NY, USA, pp 29-60.

11. Nichols HW. 1973. Growth media-freshwater. In Stein JR Jr, ed, Handbook of Phycological Methods: Culture Methods and Growth Measurements. Cambridge University Press, New York, NY, USA, pp 7-24.

12. Tan YY, Thumm W, Jobelius-Korte M, Attar A, Freitag D, and Kettrup A. 1993. Fate of two phenybenzoylurea insecticides in an algae culture system (Scenedesmus subspicatus). Chemosphere. 26:955-962. 
13. Kirschtel DB. 1992. The effects of nutrient constraint on the development of a stream periphyton community. MSci thesis. University of Louisville, Louisville, KY, USA.

14. Manthey M, Faust M, Smolka S, and Grimme LH. 1993. Herbicide bioconcentration in algae: Studies on lipophilicity-sorption-activity relationships (LSAR) with Chlorella fusca. Sci Total Environ. 1:453-459.

15. Neumann W, Laasch H, and Urbach W. 1987. Mechanisms of herbicide sorption in microalgae and the influence of environmental factors. Pestic Biochem Physiol. 27:189-200.

16. Lal R, and Saxena DM. 1982. Accumulation, metabolism and effects of organochlorine insecticides on microorganisms. Microbiol Res. 46:95-127.

17. Walker CH. 1987. Kinetic models for predicting bioconcentration factors. Environ Pollut. 44:227-239.

18. Duncan DB. 1955. Multiple range and multiple F tests. Biometrics. 11:1-41.

19. Ciba-Geigy Corporation. 1994. Environmental Fate Reference Data Source Book for Atrazine. Greensboro, NC, USA.

20. Rice CP, and Sikka HC. 1973. Uptake and metabolism of DDT by six species of marine algae. J Agric Food Chem. 21:148-152.

21. Evans MS, and McNaught DC. 1988. The effects of toxic substance on zooplankton populations: A Great Lakes perspective. Adv Environ Sci Technol. 21:53-57.
22. Biggs DC, Rowland RG, O'Connors HB Jr, Powers CD, and Wurster CF. 1978. A comparison of the effects of chlordane and PCB on the growth, photosynthesis and cell size of estuarine phytoplankton. Environ Pollut. 15:253-263.

23. Munawar M, Munawar IF, Ross PE, and Mayfield CI. 1987. Differential sensitivity of natural phytoplankton size assemblages to metal mixture toxicity. Ergebn Limnol. 25:123-139.

24. Amy GL, Bryant CW, Alleman BC, and Barkley WA. 1988. Biosorption of organic halide in a Kraft mill generated lagoon. J Water Pollut Control Fed. 60:1445-1457.

25. Harding LW, and Philips JM Jr. 1978. Polychlorinated biphenyl (PCB) uptake by marine phytoplankton. Mar Biol. 49:103-111.

26. Matter-Muller C, Gujer W, Giger W, and Stumm W. 1980. Nonbiological elimination mechanisms in a biological sewage treatment plant. Prog Water Technol. 12:299-314.

27. Baughman GL, and Paris DF. 1981. Microbial bioconcentration of organic pollutants from aquatic systems - A critical review. CRC Crit Rev Microbiol. 8:205-227.

28. Lewin RA. 1962. Physiology and Biochemistry of Algae. Academic, New York, NY, USA, pp 357-368. 